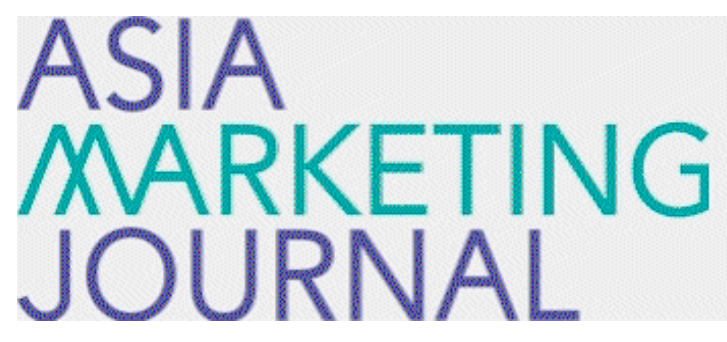

ASIA MARKETING JOURNAL

Volume 5 | Issue 4

Article 8

$12-25-2003$

\title{
대구은행의 지역밀착형 마케팅을 통한 위기극복 성공사례
}

창조 유

봉진 조

종무 박

Follow this and additional works at: https://amj.kma.re.kr/journal

Part of the Marketing Commons

\section{Recommended Citation}

유, 창조; 조, 봉진; and 박, 종무 (2003) "대구은행의 지역밀착형 마케팅을 톻한 위기극복 성공사례," Asia Marketing Journal: Vol. 5 : Iss. 4 , Article 8.

Available at: https://doi.org/10.53728/2765-6500.1119

This Article is brought to you for free and open access by Asia Marketing Journal. It has been accepted for inclusion in Asia Marketing Journal by an authorized editor of Asia Marketing Journal. 


\title{
대구은행의 지역밀착형 마케팅을 통한 위기극복 성공사례*
}

\section{Daegu Bank's Successful Management of Crisis Through Region-Oriented Marketing Activities}

\author{
유창조(동국대 경영학부 교수) \\ yoo@dongguk.edu \\ 조봉진(계명대 경영학과 교수) \\ bjcho@kum.ac.kr \\ 박종무(영남대 경영학과 교수) \\ jmpark@yu.ac.kr
}

1967년 지역사희 발전과 지역간 경제력격차의 해소를 위해 설립된 대구은행은 설립 후 30 년간 내실경영 및 경영혁신을 기반으로 1997년 총수신고 10 조의 고지를 달성하였고 지방은 행 선두자리를 확고히 한 바 있으며 일반은행권을 포함하여도 8 위권을 유지하면서 지방금융 기관으로서 자립기반을 구축한 바 있다. 그러나 1997년 말 밀어닥친 IMF 외환위기의 충격으 로 대구은행은 생존자체가 불투명해졌으나 지역사회의 뜨거운 성원과 은행 임직원의 지역밀 착형 마케팅 활동을 통하여 위기를 슬기롭게 극복하여 부실여신의 조기감축을 통한 클린뱅 크의 구현과 세계기준(Global Standard)에 부합하는 선진경영의 틀을 갖추어 나감으로써 독 자생존을 위한 기반을 마련해 나가고 있다. 본 사례는 대구은행의 IMF 사태 시 위기상황을 소개하고, 위기상황에서의 생존을 건 구조조정 프로그램과 위기관리 과정을 소개한 후, 초 일류 지역은행으로의 재탄생을 위한 기반이 되었던 지역밀착경영(K-프로젝트) 및 이와 관련 된 프로그램과 그에 따른 성과를 소개한다.

\footnotetext{
* 사례접수 : 03. 11 게재확정 : 03. 12
} 
대구은행은 1967 년 지역사회 발전과 지역간 경제력격차의 해소를 위해 설립된 후 30 년간 내실경영 및 경영혁신을 기반으로 1997년 총수신고 10조의 고지를 달성하면서 지방은행 선 두자리를 확고히 한바 있으며 일반 은행권을 포함하여도 8 위권을 유지하면서 지방금융기관 으로서 자립기반을 구축한 바 있다. 그러나 1997년 말 밀어닥친 IMF 외환위기의 충격으로 대구은행은 생존자체가 불투명해졌으나 지역사회의 뜨거운 성원과 은행 임직원의 지역밀착 형 마케팅 활동을 통하여 위기를 슬기롭게 극복하여 부실여신의 조기감축을 통한 클린뱅크 의 구현과 세계기준(Global Standard)에 부합하는 선진경영의 틀을 갖추어 나감으로써 독자 생존을 위한 기반을 마련한 바 있다. 본 사례는 1) IMF 위기 이전 30 년간 금융기관으로서의 자립기반을 구축한 과정을 간략히 요약하고, 2) 대구은행의 IMF 사태 시 위기상황을 소개하 고, 3) 위기상황에서의 생존을 건 구조조정 프로그램과 위기관리 과정을 소개한 후, 4) 초 일류 지역은행으로의 재탄생을 위한 기반이 되었던 지역밀착경영과 $\mathrm{K}$-프로젝트 및 이와 관 련된 프로그램과 그에 따른 성과를 소개한다(대구은행 2002; 대구은행 1997; 대구은행 2000 ; 대구은행 2003).

\section{1. 대구은행의 설립과 발전사 30년(1967-1997)}

대구은행은 지역자본을 육성함으로써 지역사희의 발전과 지역간 경제력 격차를 해소하고 자 했던 당시 정부의 정책의지와 지방 금융기관의 탄생을 갈망하던 대구상공업계의 주체적 인 노력의 결실로 1967년 창립되었다. 이 후 30년간 대구은행은 지역 경제발전과 지역개발 이라는 설립목적에 따라 지역사회발전에 적극 참여하고 금융환경변화에 능동적으로 대응함 으로써 30 년간 탄탄한 경영기반을 구축하고 지역중추금융기관으로서의 위상을 확고히 다진 바 있다. 아래에서는 대구은행의 30년간 발전상황을 주요 기간별로 정리하였다.

1기(1967-1972): 대구은행은 창립 후 영업기반을 강화하기 위하여 경영목표를 저축증강체 제의 구축, 환원금융체제의 확립과 신용창조의 다각화 도모, 지역밀착화를 통한 소형점포의 확대 및 지역개발을 위한 금융지원강화로 설정하고 이 목표를 달성하기 위한 기반을 착실히 구축하였다. 대구은행은 그 결과로 1972년 대구개발주식회사를 대구시와 합작으로 설립하였 고, 대구시에서는 최초의 공개법인으로 증권시장에 상장시켰으며 서울지점을 개설하여 환기 능을 강화시킨 바 있다.

2기(1973-1977): 이 시기 대구은행은 확고한 지역중추은행으로 부상을 시도하게 된다. 대 구은행은 대형화와 국제화를 위한 경영기반을 구축하고 지역사회 발전에 적극 참여하며 금 융여건 변화에 능동적으로 대웅할 수 있는 적웅력을 배양해 나간다는 경영방침을 수행하게 된다. 이를 위하여 수차례의 무상증자를 통하여 주식의 대중화를 추진했을 뿐만 아니라 자 본과 경영의 분리원칙을 확고히 하였으며 당시 번화가에만 밀집되어 있던 시중은행과는 달 리 금융소외지역으로의 과감한 진출을 통하여 지역밀착 기반을 강화하였다. 그 결과 대구은 
행의 수신고는 1977년 수신고가 1000 억을 넘어서게 되어 최우수 저축기관상을 수상한 바 있 다.

3기(1978-1980): 이 후 대구은행은 새로운 도약을 모색하기 위하여 본부기구를 확대개편 하고 본점 신축공사를 착공하였고 전산소를 신축하여 전산시스템을 도입하였으며 뉴욕사무 소를 설치하여 해외진출의 계기를 마련하는 등 새로운 도약을 위한 기반을 강화하였다.

4기(1981-1983): 그러나 1980년대 초반 국내외의 동시 불황으로 지역에 기반을 둔 기업들 이 도산 내지 휴페업하는 사태가 속출하면서 대구은행은 창사 이래 첫 번째 시련을 격게 된 다. 이러한 시련을 극복하기 위하여 대구은행은 본부기구의 축소와 신규채용의 억제 및 점 포신설 자제 등과 같은 감량경영 자구책을 강구하여 한 때 나돌았던 본점매각설을 잠재우고 1983년 본점을 완공하게 된다.

5기(1984-1987): 대구은행은 첫 번째 시련을 어느 정도 극복한 후 “새마음 새출발” 이라 는 슬로건을 내걸고 조직의 생동감과 자신감을 되살리기 시작했고 조직의 일체감을 조성하 기 위한 대구은행의 $\mathrm{CI}$ 를 확정하였고 고객지향적 업무체제를 구현하기 위한 업무개편을 단 행한 바 있으며 유망 중소기업을 적극적으로 발굴하고 지원하였다. 그 결과 대구은행은 1986년 수신고가 1조원을 돌파한 바 있고, 지방은행의 서울지점 중에는 처음으로 수신고 1000 억원을 돌파하였다.

6기(1988-1991): 이 후 대구은행은 내실경영을 기반으로 안정적인 성장을 이룩하게 된다. 1989년 정부가 지방은행의 영업구역을 동일경제권으로 확대토록 허용함에 따라 대구은행은 영업권을 부산과 경남 일원으로 확대하였고 이와 동시에 지역 내 입지강화에도 관심을 갖고 '가까운 우리은행, 편리한 대구은행' 이라는 캐치프레이즈로 지역주민들에게 막연한 애향 심보다는 편리성을 추구하기 시작하였고 지역주민을 위한 장학재단을 설립하여 지역주민과 의 우호적 관계를 구체화하였다.

7기(1992-1997): 이러한 안정적인 성장을 지속해온 대구은행은 92년 서울 및 경북지역으 로 점포를 확대하게 된다. 이러한 성장흐름에서 대구은행은 은행의 비전을 지방중추은행에 서 '21세기 초일류은행' 으로 재설정하고 이를 위한 경영혁신을 추구하게 된다. 1992년 경 영혁신위원회를 구성하여 혁신팀, 경영혁신 에이전트, 경영혁신연구회 둥을 구축하였고 1995년에는 중장기경영계흭을 실천하기 위한 목표관리(MBO)부분을 주 과제로 삼아 컨설팅을 받은 바 있다. 또한 1995년에는 2005전략경영계흭을 수립하여 중장기적인 안목에서 은행을 경영하기 시작하였고 그 결과 1 인당 업무이익과 대출금 등의 생산성지표면에서 5 대 시중은 행과의 격차를 좁혔고 1 인당 업무이익과 부가가치 등의 이익부분에서는 일부 5 대 시중은행 을 앞지르는 성과를 올린 바 있다. 또한 톰슨뱅크워치(Thomson Bank Watch) 등 국제신용평 가기관으로부터 우수등급을 획득하였으며 창립 30주년을 맞는 1997년에는 총수신고가 국내 일반은행권에서는 11 번째로 10 조원을 돌파하게 되었다.

이와 같은 대구은행의 30 년간 발전과정을 요약하면 다음 <표 1>과 같다. 
<표 1> 대구은행의 설립 후 30 년간 발전과정

\begin{tabular}{|c|c|c|}
\hline 시기 & 믁징 & 주요내용 \\
\hline 1967 1972 & 영업기반의 구축기 & $\begin{array}{l}\text { - } 1967 \text { 창립 } \\
\text { - 대구개발주식회사 설립 } \\
\text { - 증권시장 상장 } \\
\text { - 서울지점 개설 } \\
\text { - 지역일착기반 확보(신형점포 확대) }\end{array}$ \\
\hline 1973 1977 & 지역중추은행으로 부상기 & $\begin{array}{l}\text { - 지역일착기반 강화 } \\
\text { - 무상증자를 통한 주식의 대중화 유도 } \\
\rightarrow \text { 수신고 } 1000 \text { 억 돌파 }\end{array}$ \\
\hline $1978 \sim 1980$ & 도약 모색기 & $\begin{array}{l}\text { - 국내외의 동시불황으로 인한 경영환경악화 } \\
\text { - 감량경영을 통한 자구책 강구 }\end{array}$ \\
\hline 1981 1983 & 시련기 & $\begin{array}{l}\text { - 국내외 동시 불황으로 인한 지역기업 도산 } \\
\text { - 감량경영 }\end{array}$ \\
\hline $1984 \sim 1987$ & 새로운 도약기 & $\begin{array}{l}\text { - 대구은행 } \mathrm{Cl} \text { 확정 } \\
\text { - 유망중소기업의 발굴 } \\
\rightarrow \text { 수신고 1조원 돌파 }\end{array}$ \\
\hline 1988 1991 & 내실경영기 & $\begin{array}{l}\text { - 부산-경남지역으로의 영업점 확대 } \\
\text { - 지역주민을 위한 장학재단 설립 } \\
\text { - “가까운 우리은행, 편리한 대구은행” }\end{array}$ \\
\hline 1992 1997 & 경영혁신을 동한 안정적 성장기 & $\begin{array}{l}\text { - 서울·경북지역으로의 확대 } \\
\text { - 경영혁신 위원회 구성 } \\
\text { - } 2005 \text { 전락경영 계획수립 } \\
\rightarrow \text { 국제신용평가기관으로부터의 우수등급 획득 } \\
\quad \text { 수신고 } 10 \text { 조원 돌파 (국내 일반은행권에서 } 11 \text { 번째) }\end{array}$ \\
\hline
\end{tabular}

\section{2. 외환위기와 IMF체제}

1997년 11월 22일 우리나라는 외환위기를 견디지 못하고 IMF에 긴급 구제금융을 요청하게 된다. 우리나라는 70 년대 및 80 년대 고성장을 구가하였지만 그에 따른 적절한 산업구조조정 이 지연되어 고비용 저효율의 경제구조가 고착화되고 1997년부터 대기업의 부도가 가시화되 면서 외환위기는 시작되었다고 볼 수 있다. 기업도산의 확산은 금융기관의 부실화를 초래하 게 되고 특히 종금사의 경영난이 심각해지고 대외신인도가 추락하게 되며 그에 따라 외화차 입이 어려워지는 악순환이 계속되면서 외화유동성이 극도로 악화되어 환율이 급등하게 되었 다. 당시 이러한 위기를 극복하기 위하여 정부가 시장개입에 나섰으나 환율방어에 실패하면 서 IMF에 구제금응을 요청하게 되었다.

IMF 체제하에서 정부는 금융, 노동, 기업, 공공 등 4 대 부분에 대한 개혁을 중점적으로 추진함으로써 한편으로는 대외신인도제고, 선진금융관행도입, 기업 및 금응부실제거 등의 
구조조정의 성과를 거두었으나 다른 한편으로는 국가논리가 지역논리보다 우선시되면서 중 앙과 지방의 격차가 더욱 심화되고 지역금융이 더욱 위축되는 부작용을 초래하게 된다.

\section{IMF 체제하에서의 대구은행의 위기와 구조조정}

$\mathrm{IMF}$ 체제의 외환위기는 지역경제와 금융산업 전반에 혹독한 시련을 안겨 주었다. 대구은 행은 이 시기 부실규모가 엄청나게 불어나기 시작하였고 이러한 부실여신을 매각하는 과정 에서 발생한 손실 둥으로 4828 억원이라는 사상 초유의 적자를 기록하게 된다.

또한, IMF 체제하에서 대형화의 논리가 시장을 지배하는 가운데 정부의 정책이나 시장의 평가가 규모면에서 열세에 놓인 지역은행에는 불리하게 전개되고 있었다. 특히 당시 중앙과 지역 단위에서 시중은행에 의한 지역은행 합병이나 지역은행 상호간의 합병에 관한 악성루 머가 계속하여 터져 나옴으로써 대구은행의 미래에 대한 임직원과 고객들의 우려와 불안은 대구은행의 경영을 더욱 어렵게 만들고 있었다.

대구은행은 이러한 지역금융기관들의 퇴출 분위기 속에서 생존을 위한 자구책으로 우선 점포와 인력감축을 통한 감량경영을 단행하게 된다. 대구은행은 98 년과 99 년 2 년간 시외 거 점점포와 적자점포 20 여개를 폐쇄하였고 뉴욕, 홍콩, 동경 등 3 개 해외사무소를 철수하는 한편, 대은금융경제연구소와 대구리스 등의 자회사를 폐쇄하였으며 세 차례에 걸친 명예퇴 직제도를 통하여 1000 여명의 직원을 감축하였다.

이러한 노력의 결과로 1998년에 금융감독위원희 주관 하에 회계법인이 실시한 국내 은행 의 경영진단 결과 대구은행은 독자생존이 가능한 은행으로 인정을 받게 된다. 이후 금응감 독위원회가 경영개선 설문서의 작성 및 제출을 요구함에 따라 대구은행은 아더앤더슨사를 컨설팅회사로 선정하여 설문서 작성 프로젝트를 진행하였으며 그에 따라 대구은행의 생존전 략과 장기비전을 설정하였다. 당시 대구은행은 1999년 장기비전의 구체적인 전략으로 부실 자산 매각과 자기자본 확충에 힘쓰고, 비용절감을 통해 재무건전성을 확보하고, 고객 세분 화에 기반을 둔 차별화된 마케팅전략과 고객중심의 조직구조로의 개편을 추진키로 했으며 정보기술 부문에 대한 적극적인 투자와 전사적인 리스크 관리체제를 구축함으로써 내부역량 을 강화한다는 마스터 플랜을 수립한 바 있다.

\section{4. 지역밀착형 마케팅전략(K-프로젝트)의 개요}

이러한 IMF위기를 극복하고 독자생존의 경영기반을 구축하기 위한 대구은행 전략의 핵심 
은 지역밀착경영으로 요약될 수 있다. 즉, 대구은행은 경영전략의 핵심을 대구 및 경북의 종합금응서비스를 제공하는 대표은행으로서, 작지만 강한 은행을 추구하며 지역과 함께 발 전하는 은행으로 설정한 것이다. 이러한 지역밀착화 추진의 기본방향은 1) 지역밀착화 전략 의 체계화, 2) 가깝고 편리한 채널 확보, 3) 지역밀착형 상품개발, 4) 고객관리 체계화로 요약되는데 이와 관련된 내용의 개요를 <표 2>에 정리하였고 아래에서 이들을 자세히 설명 하였다.

<표 2> 대구은행의 지역밀착화 추진의 기본 방향

\section{지역밀착화 전략의 체계화}

- K-Project

\section{가깝고 편리한 재널 확보}

- 영업점

- 자동화기기

- 폰/인터넷뱅킹

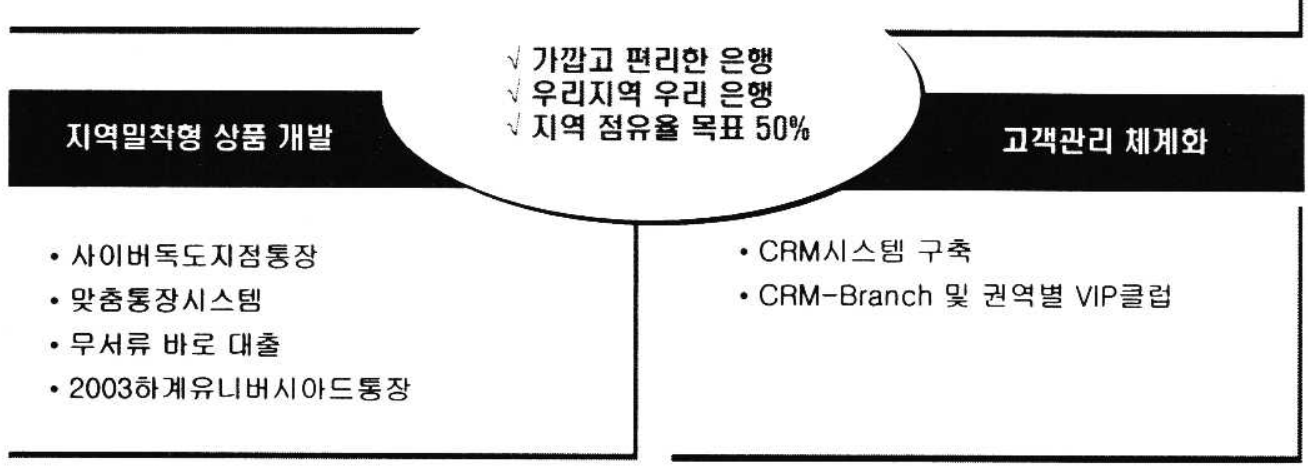

대구은행은 경영의 최우선방침으로 지역밀착경영을 선정한 후 이의 구현을 위해 은행장의 이니셜을 딴 K-project를 발진하였다. 이 프로젝트의 개요는 <표 $3>$ 에 요약되어 있다. 
<표 3> K-project의 개요

\begin{tabular}{|c|c|}
\hline 목표 & $\begin{array}{l}\text { - 지역에 기반을 둔 은행으로서 지역과 유대관계를 강화하고 지역발전에 이바지하여 } \\
\text { 궁극적으로 지역과 항께 발전을 지향코자 하는 최상위 경영이념임 }\end{array}$ \\
\hline 방향 & $\begin{array}{l}\text { - 지역일착영업기반 } \\
\text { - 지역특화 상품 및 서비스 개발 } \\
\text { - 지역기업 우대 및 경영지원 } \\
\text { - Relationship Marketing 강화 } \\
\text { - 인적네트워크 } \\
\text { - '지역일착사업반', 'OGB봉사단' 발족 } \\
\text { - } 1 \text { 점포 및 직원 } 1 \text { 인 } 1 \text { 봉사단체 가입활동 } \\
\text { - 각종 사회단체와 연계라인 구축 } \\
\text { - 사회공헌활동 } \\
\text { - '지역사회봉사상' 제정 } \\
\text { - 지역특성에 적합한 봉사활동사업의 발굴 } \\
\text { - 행정, 사회, 교육, 운화, 환경 등의 기부사업 강화 } \\
\text { - 홍보활동 강화 }\end{array}$ \\
\hline 기대되는 결과 & $\begin{array}{l}\text { - 높은 시장점유율 } \\
\text { - 지역 금융시장에서 최대의 고객수 확보 } \\
\text { - 대구은행을 '가깝고 편리한 은행'으로 인식 }\end{array}$ \\
\hline
\end{tabular}

K-project의 목표는 대구은행의 이미지를 '대구에서 유일한 우리 고장은행으로서 꿈과 풍요로움을 지역과 함께 하는 은행' 으로 형성하는 것이고 이를 통하여 대구은행이 지역과 함께 발전하고자 하는 것이다. 이를 추진하기 위한 방향으로 지역밀착기반 구축, 인적네트 워크 형성, 사희 공헌활동의 강화 및 홍보활동 강화로 설정하였고, 이러한 경영의 결과로 대구은행은 높은 시장점유율을 유지하고 지역금윰시장에서 최대의 고객수를 확보하며 고객 들에게 대구은행을 가깝고 편리한 은행으로 인식하도록 기대하였다. 이하에서는 K-project 의 추진방향을 요약하여 정리하였다.

\section{1 지역밀착을 위한 영업기반의 구축}

대구은행은 지역밀착 영업기반을 구축하기 위한 방법으로 지역특화상품 및 서비스 개발, 지역기업 우대 및 경영지원 강화 및 관계마케팅의 강화를 선정하고 이를 적극적으로 시행하 였고 이를 통하여 지역시장 선도자로서의 위상을 정립하였는데, 이들에 대한 구체적인 내용 은 지역 최고의 금융채널망 구축, 지역 특화상품 및 서비스 개발, 지역기관/단체/기업 연계 강화 및 관계마케팅 강화로 요약된다.

첫째, 대구은행은 지역최고의 금융채널망 구축을 위해 지역 내 최대 점포망 및 자동화기 기 보유를 추진하였고 고객의 폰 및 인터넷 뱅킹의 편리성 제고를 위해 과감한 투자를 아끼 


\section{지 않았다.}

둘쩨, 대구은행은 사이버 독도지점통장, 맞춤통장 및 무서류 바로대출 등과 같은 고객의 지역과 관련된 기호에 맞는 지역 특화상품 및 서비스를 개발하였는데, <표 4 >는 이들의 개 발동기, 내용 및 개발효과를 정리하였다.

<표 $4>$ 지역특화 상품의 개발- 맞춤형 상품의 개발내용

\begin{tabular}{|c|c|c|c|}
\hline & 개발동기 & 상품내용 & 개발효과 \\
\hline $\begin{array}{c}\text { 무서류 } \\
\text { 바로대촐 }\end{array}$ & $\begin{array}{l}\text { - 지역고객의 대부분이 당행을 } \\
\text { 거래하고 있다는 점에 착안하여. } \\
\text { 기존거래실적 정보룰 바탕으로 } \\
\text { 하여, 간단한 절차로 대촐울 받울 } \\
\text { 수 있게 해 줌 }\end{array}$ & $\begin{array}{l}\text { - 대상자에게 사전에 대출한도를 선정/부여 } \\
\text { 하여 통장 등에 한도를 알려 중으로써 } \\
\text { 신분중 학인만으로 전 직원이 대출을 춰급 } \\
\text { 할 수 있도록 설계 }\end{array}$ & $\begin{array}{l}\text { - 대출신규고객 } \\
113,000 \text { 명(기존 대출 } \\
\text { 고객 전체와 비숫한 } \\
\text { 숫자임), } 5,832 \text { 억원 } \\
\text { 대출 실시 }\end{array}$ \\
\hline 맞즘듕장 & $\begin{array}{l}\text { - 각 지역별, 고객별 니즈에 따라 } \\
\text { 고객이 원하는 내용으로 상뭄울 } \\
\text { 설계해 줄 수 있는 nich market } \\
\text { 공락형 상품임 }\end{array}$ & $\begin{array}{l}\text { - 본부에서 개발하여 각 지역별/고객별로 } \\
\text { 판애하는 상품(NB(National Brand) 상품) } \\
\text { 과 각 영업점 단위에서 개발하여 판애하는 } \\
\text { 상품(PB상품)으로 구분됨 } \\
\rightarrow \text { OO동창회롱장, OO지역사랑통장, } \mathrm{OO} \\
\text { 산악회롱장 등 }\end{array}$ & $\begin{array}{l}\text { - NB상품: } 9 \text { 개 } \\
\text { - PB상풍: } 18 \text { 개 } \\
\text { - 가입고객 } 42,384 \text { 명 }\end{array}$ \\
\hline $\begin{array}{l}2003 \text { 여계유니 } \\
\text { 버시아드둥징 }\end{array}$ & $\begin{array}{l}\text { - 대구시 추진사업인 하계유니버시 } \\
\text { 아드대회를 후원하고 범시인적인 } \\
\text { 분위기 조성을 위해 개발한 상품 }\end{array}$ & $\begin{array}{l}\text { - 통장 가입긍액의 일정액을 대회 성공을 } \\
\text { 위해 기부하며, 가입자 중 선발하여 자유 } \\
\text { 입장권을 증정하고 성화봉송주자로 선발항 } \\
\text { - 대회기간 중 비가 오지 않으면 대회성공 } \\
\text { 기원 금리 } 1 \% \text { 츨 추가.지급항 }\end{array}$ & $\begin{array}{l}\text { - 가입자 } 43,148 \text { 명 } \\
\text { - } 2,361 \text { 억원 시판 }\end{array}$ \\
\hline
\end{tabular}

$\checkmark$ 이외에도, IMF 이후 지역경제 회생을 기원하기 위해 시판한 경제회생한아옴통장, 지역우량고객을 한 동장으로 평생거래출 유도키 위한 평생저축레저클럽 등이 지역여론과 시민으로부터 큰 호응을 얻은 상품임

셋쩨, 대구은행은 대구뱅크플러스클럽 회원사를 확대하고 대구시 및 주요 시군 금고를 운 영하여 지역기관/단체/기업과의 관계를 강화하여 지역사회와 함께 발전하는 모습을 구현하 고자 노력하였다.

마지막으로 대구은행은 관계마케팅을 강화하여 CRM 영업점 및 시스템을 도입하고 고객관 리 프로세스를 정교하게 다듬었는데 관계마케팅의 개요는 <표 5>에 정리되어 있다. 
<표 $5>$ 관계마케팅의 체계화 개요

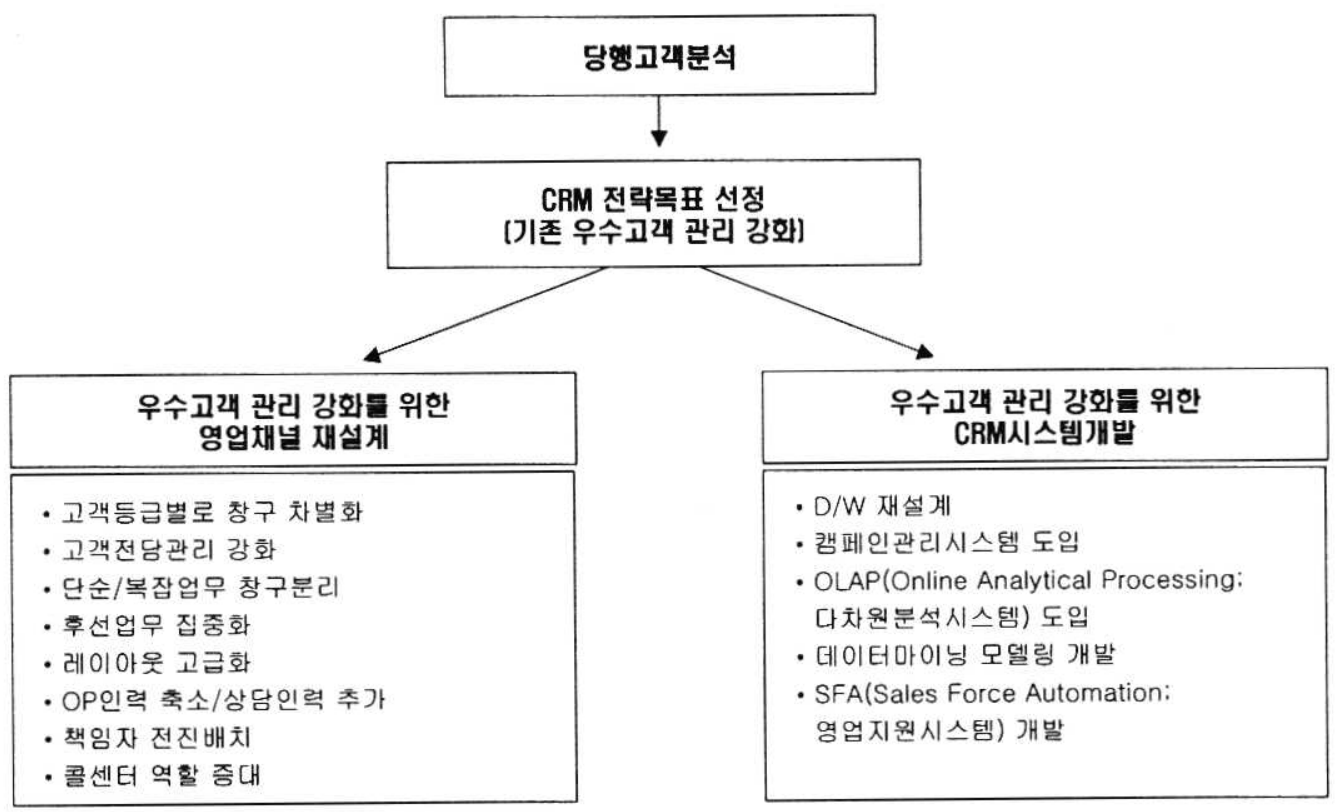

대구은행은 입금 및 지급 거래패턴을 통해 고객행동 특성을 포착하여 데이터마이닝 모델 (카드권유, 적립식 상품권유, DSS대출 권유, 거치식 상품이탈, 카드이탈, 카드 활성화, 수 신 가망 등으로 구분)을 개발하였고 데이터 마이닝을 통하여 파악된 가망고객은 전담직원별 로 자동 할당되도록 하였다. 한편 대구은행은 당행의 고객을 PB대상 고객, 우수 고객, 우량 고객 및 일반 고객으로 구분하여 이들에 대한 전담관리를 강화하기 위해 고객별 관리채널을 재정의한 바 있다. 대구은행은 2003년 6월 현재 7 개 점포를 CRM점포로 운영 중이고 이들의 도입효과는 <표 6>에 정리되어 있다. 이와 같이 CRM점포가 다른 점포보다 우수고객수의 증 가율이 높은 것으로 나타나고 있어 대구은행은 조속한 시간 내에 이러한 제도의 도입을 전 점포로 확대할 계획을 가지고 있다. 
<표 6> CRM점포의 도입효과

(단위 : 억원, 명)

\begin{tabular}{|c|c|c|c|c|}
\hline & 구분 & 20002. 2월 & 2002. 9월 & 증가을 \\
\hline \multirow{3}{*}{$\begin{array}{l}\text { CRM-Branch } \\
\text { [B 지점] }\end{array}$} & 총수신 & 861 & 1.053 & $22.3 \%$ \\
\hline & 수신5천만원 이상 고객수 & 173 & 216 & $24.9 \%$ \\
\hline & 우수고객수 & 395 & 518 & $31.1 \%$ \\
\hline \multirow{3}{*}{ 은행전쳬 } & 총수신 & 119,680 & 128,514 & $7.4 \%$ \\
\hline & 수신5천만원 이상 고객수 & 28,300 & 31,392 & $10.9 \%$ \\
\hline & 우수고객수 & 49,118 & 57,308 & $16.7 \%$ \\
\hline
\end{tabular}

\section{2 인적 네트워크의 구축}

인적 네트워크의 구축은 직원과 고객 및 은행과 고객의 관점에서 주요활동이 설계되었는 데 직원별로 한 개 이상의 단체에 가입하거나 은행에 대한 우호조직의 유도 및 확대 등을 통하여 은행관련 네트워크를 형성하는 것으로서 그 활동 내용이 <표 $7>$ 에 요약되어 있다.

<표 7> 인적 네트워크 구축을 위한 주요활동

\begin{tabular}{|c|c|}
\hline 구분 & 내용 \\
\hline 영업점 고계 조직화 & $\begin{array}{l}\text { - 직원 } 1 \text { 인 } 1 \text { 단체 가입 } \\
\text { - 영업점 애월 } 1 \text { 회 이상 봉사활동 실시 }\end{array}$ \\
\hline 우호조직 구성 및 합성화 & - 대구경영자회, 대구시 골프연합회 등 우호조직을 주도적으로 구성, 확대 \\
\hline 명예지점장 제도 실시 & - 영업점주 유력인사와 의견선도자률 1 년간 명예지점장으로 임영하여 지속관리 \\
\hline 인력운용의 효율화 & $\begin{array}{l}\text { - 지역일착사업 강화를 위한 장기근무 } \\
\text { - 지역인재 고용창출 }\end{array}$ \\
\hline
\end{tabular}




\section{3 사회공헌활동의 강화}

대구은행은 사회공헌활동을 강화함으로써 지역주민과의 우호적인 관계를 유도할 뿐만 아 니라 지역사회와의 동질감을 확보하여 함께 성장하고 발전하는 공유의식을 유도하고자 하였 는데, 주요 활동을 요약하면 <표 8>과 같다.

<표 8> 사회공헌활동의 주요 내용

\begin{tabular}{|c|c|}
\hline 구분 & 내용 \\
\hline DGB봉사단 조직 및 할동 & $\begin{array}{l}\text { - 봉사단원: 은행직원 } 266 \text { 명 } \\
\text { - 사랑의 헌혈운동 } \\
\text { - 사회복지시설 방문 } \\
\text { - 수해지역 복구사업 참여 } \\
\text { - 2002년 푸른 대구 가꾸기 참여 }\end{array}$ \\
\hline 지역사랑 운동 전개 & $\begin{array}{l}\text { - 금호강 사랑운동 캠페인 } \\
\text { - 독도사랑운동: 탕사대 파견, 독도박물관 기부 } \\
\text { - 상주시인봉사상 제정 }\end{array}$ \\
\hline 각종 기금 츨연 & $\begin{array}{l}\text { - 체육진홍기금 출연 등 각종 지역 관련 기금 조성 및 출연 } \\
\text { - 교육 장학사업 출연 및 지원 }\end{array}$ \\
\hline 불우이웃 돕기 & $\begin{array}{l}\text { - 수재민돕기 성금 } \\
\text { - 결식아동돕기 }\end{array}$ \\
\hline
\end{tabular}

\section{4 대구은행 브랜드 가치제고를 위한 홍보할동의 강화}

대구은행은 위에서 언급한 활동을 추진함과 동시에 당행의 브랜드 가치제고를 위한 다양한 홍보활동을 전개하고 있다. 지역공헌 사업에 대한 홍보로 지역봉사 미담사례를 알리고 지역 사랑 공익광고를 전개하고 있고, 지역문화사업을 활성화하기 위하여 지역문화 바로알기 사 업을 전개하고 지역사랑지 '향토와 문화' 를 편찬하였으며 지역 현안 행사(월드컵 자원봉 사. 입시 설명회 및 심포지움 개최 등)를 주관하여 지역주민의 참여를 유도하는 등 다양한 활동을 전개한 바 있다.

\section{5 지역밀착경영의 성과}

대구은행은 IMF 이후 1998년 4828에 달하는 적자를 기록하기도 하였으나 이 후 뼈를 깎는 구조조정과 지역밀착경영의 결과 2002 년에는 1312 억에 달하는 사상최대의 당기순이익을 기 
록하게 되었으며 2003 년에는 2000 억원 이상의 순익을 기대하고 있다.

대구은행은 이러한 외적 성과뿐만 아니라 내적 경쟁력도 강화되고 있는 것으로 나타나고 있다. 대구지역 수신점유율은 97년 36.6\%에서 2002년 40.2\%로 증가하였고 타지방은행의 해 당지역 시장점유율이 $30 \%$ 미만임을 감안하면 대구은행의 지역밀착경영은 실효를 거두고 있 다고 하겠다.

\section{5. 사례의 시사점}

\section{1 시사점}

기업의 적절한 전략적 선택은 기업의 생존여부에 지대한 영향을 미친다. 대구은행의 사례 는 IMF와 같은 통제 불가능한 요인, 즉 외부환경의 쇼크로 야기된 위기에 신속하게 적응하 는 기업의 대처능력의 중요성을 잘 보여주고 있다. 대구은행은 생존전략의 핵심으로 외부환 경과의 구조적인 적합성(structural fit)에 맞추었고 그 전략의 기본의 체계적인 구체화를 기하였으며 이를 신속히 실행에 옮겼기 때문에 생존이 가능했던 것으로 보인다 (안광호, 김 동훈, 김영찬 2002). 대구은행은 앞서 설명한 대로 지역밀착경영을 통하여 IMF 위기를 슬기 롭게 극복하여 왔다고 볼 수 있다. IMF 당시 대구은행이 추구한 지역밀착경영은 지방은행으 로서의 퇴출위기를 극복하기 위한 가장 적절한 전략적 선택이었던 것으로 평가될 수 있다. 그에 따라 대구은행이 추진하였던 여러 가지 활동들과 현재 진행되고 있는 사업들은 대구은 행이 우량은행으로 재탄생하고 자립기반을 확보하는데 기여할 것이다.

\section{2. 대구은행의 미래와 과제}

그러나 대구은행에게 밝은 미래만 있다고 보기 어렵다. 급속하게 변하는 금융환경 및 소 비자의 금융관련 욕구 변화에 능동적으로 대처하기 위하여 대구은행은 대구은행만이 가지는 핵심역량을 키워야 한다. 현재 대구 및 인접지역의 소비자들이 대구은행에 대하여 갖고 있 는 주 이미지는 “지역경제에 대한 기여도” 로 평가되고 있다(1999년 대구은행 마케팅 조사 결과 보고: 대구은행 고객지원부). 이는 대구은행이 추구해 온 지역밀착경영의 긍정적 결과 로 평가될 수 있지만, 이는 또한 지역밀착경영의 한계로 평가될 수도 있다. 즉, 대구은행이 가지고 있는 지역성은 위기상황시 소비자들에게 가장 잘 소구되는 요소이기는 하지만 그 자 체가 경쟁우위라고 보기 어렵기 때문이다. 앞으로 대구은행이 추구해야 할 가장 중요한 과 제는 금윰시장에서 대구은행만이 가질 수 있는 경쟁우위 요소를 확보하고 이 요소가 대구은 행의 지역대표성과 조화될 수 있도록 관리하는 것이라고 볼 수 있다. 
또한 대구은행이 앞으로 대구지역에서 추구하는 기반을 성공적으로 구축한다고 가정하면 그 다음과제가 무엇일 것인가를 미리 생각해 볼 필요가 있다. 은행의 특징으로 볼 때 점포 망의 확대가 불가피하게 고려될 가능성이 높다. 만일 미래에 대구은행이 점포망의 확대를 다시 시도하게 된다면 현재 가지고 있는 '지역대표성' 이미지는 가장 큰 장애요인이 될 가능성이 높기 때문이다.

결국 대구은행은 지역대표성이 아닌 다른 경쟁우위요소를 시급히 구축해야 한다. 지역밀 착형이라는 개념은 대구지역에게만 적용되는 것이 아니라 모든 지역에서 적용될 수 있는 유 연한 개념으로 재정의되어야 하고 이에 대한 대구은행의 새로운 시각이 필요한 시점이라고 하겠다. 


\section{<참고문헌>}

대구은행 (1997), 제 7차 중기경영계획, 대구은행 보고서.

대구은행 (2000), 제 8차 중기경영계획, 대구은행 보고서.

대구은행 (2002), 지역사랑 35년, 삼성인쇄.

대구은행 (2003), 초우량지역은행 대구은행의 전략과 비전.

안광호, 김동훈, 김영찬 (2002), 시장지향적 마케팅전략, 학현사. 